\title{
How do Rodents Play Role in Transmission of Foodborne Diseases?
}

\author{
Kordiyeh Hamidi* \\ Faculty of Science, Ferdowsi University of Mashhad, Iran
}

Submission:February 06, 2018; Published: April 06, 2018

*Corresponding author: Kordiyeh Hamidi, Department of Biology, Faculty of Science, Ferdowsi University of Mashhad, Mashhad, Iran, Tel: +989151098715; Email: kordiyeh.hamidi@yahoo.com

\begin{abstract}
Among the major pests affecting the food products, rodents are well known as a source of foodborne diseases. In this review I focused on the role of rodents in transmission of foodborne diseases. They spread diseases, contaminate food, water and products, destroy crops, and also damage food stocks and properties. Almost all reported cases of foodborne diseases are caused by pathogenic bacteria or by the poisons produced by them. Clostridium perfringens, Escherichia coli., Listeria monocytogenes, Salmonella enteriditis and S. typhymurium are most frequent pathogenic bacteria transmitted to foods by rodents. Pest rodents entering or infesting food products or establishments, or poorly executed rodent control programs are potential sources of physical, microbiological and chemical hazards. Hence, monitoring pests, good hygiene practices during preparation, storing and serving food products, keep food safe with time and temperature control, and checking the health of food service personnel are recommended to prevent foodborne illness which is a major concern in the food service establishment.
\end{abstract}

Keywords : Rodents infestation; Food contamination; Disease transmission; Public health; Pests

Abbreviations : RBF: Rat Bite Fever; HPS: Hantavirus Pulmonary Syndrome

\section{Introduction}

\section{Rodents as a source of contamination}

Most of the foods linked to food infections or food intoxications (a foodborne illness caused by a toxin released by microbes) are from animal sources. Pathogens have been found to enter the food supply through animal carriers, animal hosts or improper handling procedures. The major groups of pests affecting the food products include rodents (especially murine rodents), birds (mainly crows, pigeons, seagulls, starlings and sparrows), reptiles (such as different species of lizards), insects (e.g. cockroaches, mosquitoes, flies, beetles, ants, wasps, bees, bugs, lice), and stored product insects (such as beetles, weevils, moths, ticks and mites), as well as domestic animals [1-6].

Rodents which represent more than $40 \%$ of species diversity within the class Mammalia, have a worldwide distribution and can be found in every habitat. The house mouse (Mus musculus), the black rat (Rattus rattus), the brown rat (Apodemus spp.) and the field mouse (Apodemus spp.) which belong to family Muridae and the cotton rats (Sigmodon hispidus) and the woodrats (Neotoma spp.) of family Cricetidae are small rodents which live in close association with humans. Squirrels of the family Sciuridae have also a somehow worldwide distribution and live alongside humans [7]. These rodents are well known as a source of foodborne diseases. They are attracted by food supplies but do not venture far from their nesting sites or shelters. Three basic requirements that a rodent need are harborage (places to hide and nest), food, and water. Decrease in rodent populations distributed in an area usually is expected if one or more of these items are missing. Because of their ecology, these rodents nest close to food sources, eat poultry feed, contaminate food with their droppings, urine and filth and ruin crops, food containers and packaging much more than they eat. Furthermore, they have good reproduction capabilities and pose a particular threat as they live close to humans and livestock. Pathogenic agents can also be introduced onto soils, water supplies, vegetables and fruits by rodents (Weil's disease and hepatitis). Moreover, they are considered as important pests around farms and homes due to physical damage to the building and equipment (such as gnawing on electrical wiring and damage to machinery, power failures or operational shutdowns due to electrical or mechanical malfunctions, burrowing under walls and concrete walkways causing shifting and cracks) $[4,8,9]$. In this review I have focused on the role of rodents in transmission of foodborne diseases. 


\section{Foodborne diseases}

Foodborne illnesses are any infections or diseases caused by eating contaminated foods or drinks. Almost all reported cases of foodborne diseases are caused by pathogenic bacteria or by the poisons produced by them. However, some illnesses are caused by parasitic or viral agents. Some parasites that cause foodborne illness are commonly found in contaminated water supplies, raw meat, fresh fruits and vegetables. Viruses are usually transmitted through the fecal-oral route. The typical symptom of a foodborne illness is stomach flu. Other symptoms include vomiting, diarrhea and stomach cramps. Each year, approximately 76 million cases of foodborne diseases are recorded. Hence, prevention of foodborne diseases is a major concern in the food service establishment [10-12].

\section{List of Rodent's Infections of Significant Public Health Importance}

Rodents have the capability to spread many human pathogens. They carry different pathogens on their skins and in their digestive system such as Borrelia spp., Campylobacter spp., Clostridium spp., Cryptosporidium parvum, Escherichia coli. (E. coli.), Leptospira spp., Listeria spp., Mycoplasma spp., Salmonella spp., Staphylococcus aureus, Streptobacillus moniliformis, Toxoplasma spp., Trichinella spp., Francisella tularensis, Yersinia pestis, and Hantaviruses. They also cause infectious diseases such as campylobacteriosis, ascaridiasis, Bubonic plague, capilariasis, coli.bacillosis, hemorrhagic enteritis, hymenolepiasis, leptospirosis, listeriosis, lyme disease, mycoplasmosis, pasteurellosis, rat bite fever (RBF) or Haverhill fever, salmonellosis, toxoplasmosis, trichinosis, tularemia and Hantavirus pulmonary syndrome (HPS) $[5,6,10,13,14]$. As follows, some common important foodborne diseases with baseline information are presented:

Clostridium perfringens and E.coli. are two pathogenic bacteria. The first one causes one of the most frequent forms of food intoxication. This gram-positive bacterium is widespread in nature and is found in air, soil, water, sewage, and on many food products. The second pathogen, E.coli., live in the colons of humans, rodents and other mammals, and help break down waste products. However, whenever they enter the stomach and small intestines, they can cause illness. E.coli. can be passed out of the body in feces. Listeriosis is another foodborne infection caused by the bacteria species Listeria monocytogenes. This rod-shaped, gram-positive bacterium is found in soil, water and many species of animals and caused flu-like symptoms. This infection in pregnant women can result in miscarriage or stillbirth. Nearly $25 \%$ of serious cases result in death. Salmonella is a genus of rod-shaped, gramnegative bacteria which cause an illness called salmonellosis. $S$. enteriditis and $S$. typhymurium are most frequent isolated form from mice. These pathogenic bacteria can survive on people's hands for hours before being transmitted to foods and are often spread from one food to another by food handlers.
Animal and human excreta, insects, soil, dust and raw meat are as the sources of this pathogen [11,15-17].

Trichinella spiralis as a pathogenic roundworm is probably the best known endoparasite that causes foodborne illness. An infection caused by this microscopic worm is known as trichinosis. It occurs in wild animals, such as bears, boars, rodents and rabbits, as well as humans. This parasite can enter a host as larvae or adult worms through infected food. Hantavirus pulmonary syndrome (HPS) is a deadly viral disease caused by Sin Nombre, or the "No Name Virus". A wide variety of wild rodents such as cotton rat (Sigmodon hispidus), rice rat (Oryzomys palustris), deer mouse (Peromyscus maniculatus) and (Peromyscus leucopus) are reservoirs for this virus $[10,12,15]$.

\section{Signs of Rodent's Infestation}

Signs of pest infestation are including one or more of different items such as presence of rodent feces or small droppings, animal footprints, greasy smear marks along walls or tail streaks, nest holes or burrows, evidence of gnawed holes, physical damage to food, food packaging and property, damaged crops and plants, visual sighting of live rodents, uptake of bait at baiting points or from pest traps, and musty smell where heavy infestations exist $[4,8,9]$. It is very important to estimate how serious a rodent infestation problem is in order to attack the disaster.

For Determination the Rodent Populations there is a Fairly Reliable Rule of Thumb as Follows

If signs seen but no rodents seen, the population is estimated about 1 to 100 on the premises. Hundred to 500 and 500 to 1000 on the premises are considered for occasional sightings at night and nightly sightings or occasional daytime sightings, respectively. For several seen during the day, estimation up to 5000 on the premises is considered. Finally, for every rodent seen, it is estimated that there are likely 20 to 50 individuals that are unseen. Using tracking dust (finely ground and unscented materials such as flour or if possible, a non-food alternative such as china clay) is suggested to determine the presence and direction of travel of rodents. A fluorescent version of tracking powder is also available. Traces of the dust leaved by rodents are illuminated when exposed to a special lamp with ultra-violet light $[1,4,8,9]$.

\section{Preventing Foodborne Illnesses: Food Protection and Pest Management}

We need to prepare and store our food very carefully. Hence, the main reasons for control programs are to eliminate or reduce contamination of products, damaging to food stocks and properties and also spreading of disease. Monitoring the safety of the food should be considered from the crop stage through to the storage of food in both commercial and domestic premises. A rodent control program that includes 
sanitation, rodent-proofing, population reduction, evaluating and monitoring the rodent situation is a critical part of every management program. Pests require food, water and shelter to survive, hence food operators need to eliminate these conditions to prevent rodent infestation. Moreover, they should reduce the risk of foodborne diseases transmitted by rodents through considering following points:

Take account of all potential entry points (e.g. windows, doors, ventilation inlets/outlets, drains); consider ways of minimizing the risks such as self-closing door mechanisms, air curtains, wire mesh screens to pest proof air vents, use traps or pesticides; make adequate provision for the storage and disposal of food waste and other refuse; keep all storage areas clean, remove vegetation, pallet stacks and disused equipment to minimize the possibility of providing food and refuge to pests; follow good food hygiene practices including protection against contamination and pest control; store food in rodent-proof containers; perform water treatment (involves sedimentation, filtration and chlorination or UV treatment) to remove pathogenic agents; train and instruct staff to recognize signs and action to take on whenever they see rodents; check regularly all areas of the food premises for signs of pests; take immediate management and appropriate action to control any identified infestation; thoroughly soak or spray any dead mice, dropping, traps or nests with a $10 \%$ solution of chlorine bleach or a commercial disinfectant solution [2-4,9,17-19].

\section{Discussion and Conclusion}

Pest rodents infesting or entering food products or properties are a potential source of physical and microbiological hazards. Use of rodenticides, careless storage, and poorly executed rodent control programs may also result in chemical hazards. Hence, good hygiene as well as the five basic points for safe and sanitary food service is strictly advised as follows:

protecting food from dirty equipment, vermin, animals, wastes, handling, coughs and sneezes during preparation, storage and service; keeping temperature cold to slow or stop the growth of germs for cold foods, also hot foods should be kept hot because heat kills germs; handling, washing and carefully storing utensils in the correct way to keep them sanitary; cleaning and washing hands with soap and water before work, after using toilet and every time they become contaminated; checking the health of food service personnel to prevent colds and other diseases from being passed to others $[4,9]$.

\section{Acknowledgement}

Author wishes to express her sincere thanks to A. Hamidi for her critical review of the first draft of the manuscript.

\section{References}

1. Donald J, Eckman M, Simpson G (2002) How to control rats, mice, and darkling beetles. Poultry Engineering, Economics, and Management Newsletter. No. 20. November. Auburn University. Auburn, AL, USA.
2. Meerburg BG, Bonde M, Brom FWA, Endepols S, Jensen AN, et al. (2004) Towards sustainable management of rodents in organic animal husbandry. NJAS-Wageningen J Life Sci 52(2): 195-205.

3. Meerburg BG, Jacobs-Reitsma W, Wagenaar J, Kijlstra A (2006) Presence of Salmonella and Campylobacter spp. in wild small mammals on organic farms. Appl Environ Microbiol 72(1): 960-962.

4. Loven J (2010) Controlling rodents in commercial poultry facilities. Purdue Cooperative Extension Service. West Lafayette, IN, USA.

5. Hamidi K, Nourani L, Moravvej GH (2015) The relationship of ectoparasite prevalence to the capturing season, locality and species of the murine rodent hosts in Iran. PJA 4(4): 409-423.

6. Hamidi K, Nourani L, Moravvej GH (2016) New rodents' hosts of sucking lice, fleas (Insecta: Anoplura, Siphonaptera) and hard ticks (Acari: Ixodida) from Iran. PJA 5(1): 85-88.

7. Grzimek B (2004) Grzimek's Animal life encyclopedia. (2 $\left.2^{\text {nd }} e d n\right)$. Volumes 12-16, Mammals I-V, edited by Michael Hutchins, Devra G. Kleiman, Valerius Geist, and Melissa C. McDade. Farmington Hills, MI: Gale Group. Volume 16.

8. Berry J (2003) Rodent control in the poultry house. Oklahoma Cooperative Extension Service. Oklahoma State University, Stillwater, OK, USA.

9. Tabler T, Farnell M, Wells J, Yakout H, Liang Y (2014) Controlling rodents on the poultry farm. Mississippi State University, USA, pp. 7.

10. Krauss H, Weber A, Appel M, Enders B, Isenburg HD, et al. (2003) Zoonoses: infectious diseases transmissible from animals to humans. Washington DC, ASM Press, USA, pp. 214-215.

11. Szyfres B, Acha PN (2003) Zoonoses and communicable diseases common to man and animals. Parasitic Zoonoses. Pan American Health Org, USA.

12. Peters CJ (2006) Emerging infections: lessons from the viral hemorrhagic fevers. Trans Am Clin Climatol Assoc 117: 189-197.

13. Moravvej G, Hamidi K, Nourani L, Bannazade H (2015) Occurrence of ectoparasitic arthropods (Siphonaptera, Acarina, and Anoplura) on rodents of Khorasan Razavi Province, northeast of Iran. Asian Pac J Trop Dis 5(9): 930-934.

14. Hamidi K (2015) First parasitological survey of Calomyscus elburzensis (Rodentia; Calomyscidae); two new records of tick from Iran. J Zool St 2(2): 42-46.

15. Ryan KJ, Ray CG (2004) Sherris medical microbiology: an introduction to infectious diseases, ( $4^{\text {th }}$ edn). Newyork: McGraw-Hill, USA.

16. Meerburg BG, Kijlstra A (2007) Role of rodents in transmission of Salmonella and Campylobacter. J Sci Food Agric 87: 2774-2781.

17. Ambu S (2014) Rodents and disease - the never ending problem. IeJSME 8(1): 1-2.

18. Dziuban EJ, Liang JL, Craun GF, Hill V, Yu PA, et al. (2006) Surveillance for waterborne disease and outbreaks associated with recreational water-United States, 2003-2004. MMWR: Surveillance Summaries 55(SS12): 1-24. 
19. Oglesbee BL (2011) Blackwell's five-minute veterinary consult: small

This work is licensed under Creative Commons Attribution 4.0 License

DOI: $10.19080 / N F S I J .2018 .06 .555683$ mammal, ( ${ }^{\text {nd }}$ edn $)$. John Wiley \& Sons, Inc, USA.

\section{Your next submission with Juniper Publishers} will reach you the below assets

- Quality Editorial service

- Swift Peer Review

- Reprints availability

- E-prints Service

- Manuscript Podcast for convenient understanding

- Global attainment for your research

- Manuscript accessibility in different formats

( Pdf, E-pub, Full Text, Audio)

- Unceasing customer service

Track the below URL for one-step submission https://juniperpublishers.com/online-submission.php 